Z. Anal. Chem. 280, 220 (1976) - (C) by Springer-Verlag 1976

\title{
Spectrophotometric Determination of Copper(II)
} with 1-Benzoyl-3-(2-pyridyl)-2-thiourea

D. N. Wandalkar and A. P. Joshi

Chemistry Dept., Nagpur University, Nagpur, India

Received August 2, 1975; revised December 1, 1975

Spektralphotometrische Bestimmung von Kupfer(II) mit 1-Benzoyl-3-(2-pyridyl)-2-thioharnstoff

Best. von Kupfer(II) mit 1-Benzoyl-3-(2-pyridyl)-2-thioharnstoff; Spektralphotometrie

A procedure is presented here for the rapid extraction and spectrophotometric determination of copper(II) using 1-benzoyl-3-(2-pyridyl)-2-thiourea as reagent. The absorbance of the coloured complex formed is stable for more than $48 \mathrm{~h}$. Beer's law is obeyed within the range of $5-35 \mu \mathrm{g}$ of $\mathrm{Cu}$. The composition of the complex has been found to be $1: 2$ (Cu: reagent). Sensitivity according to Sandell is $3.36 \times 10^{-3} \mu \mathrm{g} / \mathrm{cm}^{2}$. Relative mean deviation is $0.7 \%$. Time required for one determination is $15 \mathrm{~min}$. Tolerance limits for foreign ions can be seen from Table 1. Strong interferences are caused by $\mathrm{Cr}^{6+}, \mathrm{Mn}^{2+}, \mathrm{V}^{5+}, \mathrm{Fe}^{3+}, \mathrm{Th}^{4+}$ and $\mathrm{Ce}^{4+}$. Iron, however, can be masked by triethanolamine and then does not interfere up to $300 \mu \mathrm{g}$. Optimum working conditions have been incorporated in the following direction.
Table 1. Effect of diverse ions. $[\mathrm{Cu}]=25 \mu \mathrm{g}, \mathrm{pH} 5.0$

\begin{tabular}{ll}
\hline $\begin{array}{l}\text { Tolerance } \\
\text { limit }\end{array}$ & Ion present \\
\hline $1.0 \times 10^{4}$ & $\mathrm{Na}^{+}, \mathrm{K}^{+}, \mathrm{NO}_{3}^{-}, \mathrm{Cl}^{-}, \mathrm{SO}_{4}^{2-}$ \\
$5.0 \times 10^{3}$ & $\begin{array}{l}\mathrm{Ca}^{2+}, \mathrm{Ba}^{2+}, \mathrm{Sr}^{2+}, \mathrm{UO}_{2}^{2+}, \mathrm{PO}_{4}^{3-}, \mathrm{S}_{2} \mathrm{O}_{3}^{2-}, \mathrm{Br}^{-}, \\
\mathrm{I}^{-}, \mathrm{F}^{-}, \text {tartrate }\end{array}$ \\
$1.0 \times 10^{3}$ & $\mathrm{Ni}^{2+}, \mathrm{Pb}^{2+}, \mathrm{Bi}^{3+}, \mathrm{Zr}^{4+}, \mathrm{Mo}^{6+}, \mathrm{Mg}^{2+}$ \\
$5.0 \times 10^{2}$ & $\begin{array}{l}\mathrm{Zn}^{2+}, \mathrm{Co}^{2+}, \mathrm{Pd}^{2+}, \mathrm{Cd}^{2+}, \mathrm{NO}_{2}^{-}, \mathrm{EDTA}^{2}, \\
\text { malonate }\end{array}$ \\
\hline $1.0 \times 10^{2}$ & $\mathrm{SCN}^{-}, \mathrm{C}_{2} \mathrm{O}_{4}^{2-}, \mathrm{CH}_{3} \mathrm{COO}^{-}$, citrate \\
\hline
\end{tabular}

Procedure. Mix $5 \mathrm{ml}$ of sample solution (containing about $25 \mu \mathrm{g}$ of $\mathrm{Cu}$ ) with $4 \mathrm{ml}$ of $10^{-4} \mathrm{M}$ alcoholic reagent solution. (The reagent is prepared by reaction of benzoylisothiocyanate with 2-aminopyridine in acetone medium.) Adjust the $\mathrm{pH}$ to 5.0 with $\mathrm{HCl}$ and $\mathrm{NaOH}$ solutions, fill up to $25 \mathrm{ml}$ and shake with two $5 \mathrm{ml}$ portions of chloroform for $2 \mathrm{~min}$ each. Withdraw the organic layers into a $10 \mathrm{ml}$ flask and make up to the mark. Measure the absorbance at $340 \mathrm{~nm}$ against a reagent blank. Prepare a calibration curve accordingly.

Acknowledgement. The authors are thankful to Prof. R. H. Sahasrabudhey, Head of Chemistry Department, for facilities and encouragement.

Dr. A. P. Joshi, Chemistry Department, Nagpur University, Nagpur-440010, India 